NBER WORKING PAPER SERIES

\title{
DOES LINKING WORKER PAY TO FIRM PERFORMANCE HELP THE BEST FIRMS DO EVEN BETTER?
}

\author{
Douglas L. Kruse \\ Joseph R. Blasi \\ Richard B. Freeman \\ Working Paper 17745 \\ http://www.nber.org/papers/w17745
NATIONAL BUREAU OF ECONOMIC RESEARCH
1050 Massachusetts Avenue
Cambridge, MA 02138
January 2012

This research was made possible with the gracious cooperation of Amy Lyman and the Great Place to Work ${ }^{\circledR}$ Institute. It was supported by an Officer Grant from the Alfred P. Sloan Foundation to $\mathbb{M} \mathrm{KH}$ School of Management and Labor Relations at Rutgers, and by the Foundation for Enterprise Development which funded the Beyster Faculty Fellowships for Kruse and Blasi at Rutgers. The views expressed herein are those of the authors and do not necessarily reflect the views of the National Bureau of Economic Research.

NBER working papers are circulated for discussion and comment purposes. They have not been peerreviewed or been subject to the review by the NBER Board of Directors that accompanies official NBER publications.

(C) 2012 by Douglas L. Kruse, Joseph R. Blasi, and Richard B. Freeman. All rights reserved. Short sections of text, not to exceed two paragraphs, may be quoted without explicit permission provided that full credit, including (C) notice, is given to the source. 
Does Linking Worker Pay to Firm Performance Help the Best Firms Do Even Better?

Douglas L. Kruse, Joseph R. Blasi, and Richard B. Freeman

NBER Working Paper No. 17745

January 2012

JEL No. J33,J53,J54,J63,M50,M52,M54,P12,P13,P17

\begin{abstract}
This paper analyzes the linkages among group incentive methods of compensation, labor practices, worker assessments of workplace culture, turnover, and firm performance in a non-representative sample of companies: firms that applied to the " 100 Best Companies to Work For in America" competition from 2005 to 2007. Although employers with good labor practices self- select into the 100 Best Companies firms sample, which should bias the analysis against finding strong associations among modes of compensation, labor policies, and outcomes, we find that in the firms that make more extensive use of group incentive pay employees participate more in decisions, have greater information sharing, trust supervisors more, and report a more positive workplace culture than in other companies. The combination of group incentive pay with policies that empower employees and create a positive workplace culture reduces voluntary turnover and increases employee intent to stay and raises return on equity. Finding these effects in the non-representative "100 Best Companies" sample strengthens the likelihood that the policies have a causal impact on employee well-being and firm performance.
\end{abstract}

Douglas L. Kruse

School of Management and Labor Relations

Rutgers University

94 Rockafeller Road

Piscataway, NJ 08854

and NBER

kruse@smlr.rutgers.edu

Joseph R. Blasi

Rutgers University

School of Management and Labor Relations

200 B Levin Building

Rockefeller Road

New Brunswick, NJ 08903

and NBER

blasi@smlr.rutgers.edu
Richard B. Freeman

Harvard and NBER

1050 Massachusetts Avenue

Cambridge, MA 02138

freeman@nber.org 
This paper examines how employee compensation and managerial personnel practices affect employee well-being and firm performance among a special group of firms - those that applied to the Great Place to Work ${ }^{\circledR}$ Institute competition to become one the " 100 Best Companies to Work For in America” that Fortune magazine publishes each year. Our 100 best data set include firms that made the list and those that applied but did not make the list, and the firm and employee surveys that are part of the application process, none of which was available to earlier studies of 100 best companies (Edmans, 2011; Faleye and Trahan, 2011). Because applicants to the 100 best list view their workplace policies and practices as exemplary, estimates of the link between those practices and worker and firm outcomes in this data set are likely to be biased downward compared to estimates that one would obtain from a random sample of firms. Thus, the data provide a high hurdle for claims that particular compensation policies and practices improve outcomes.

The Great Place to Work (GPTW) data set contains information on the 780 firms that applied for the 100 best list in 2005-2007. The firms tend to be large. About half are public firms that in 2007 employed about 6 million workers or around 5\% of the private sector workforce. Information on the firm's compensation policies and turnover rates comes from the firm's application to be considered for the list. Information at the individual level about work practices and workplace culture comes from a survey that the Great Place to Work ${ }^{\circledR}$ Institute conducts among 200-300 randomly chosen workers within the workforce of every applicant company. We obtain additional data for the economic performance of public companies from Standard and Poor's Compustat file.

The GPTW dataset allows us to examine the link between three forms of compensation that tie employee earnings to the performance of the firm - employee stock ownership, profit and gain sharing, and broad-based stock options, which we have labeled elsewhere as shared capitalist compensation (Kruse, Freeman, Blasi, 2010) - and worker reports on managerial practices and workplace culture. We estimate the link from shared capitalist compensation, work practices, and workplace culture to worker and firm outcomes.

We find that:

1) There is great variation among the applicants to the "100 best companies to work for" list in their use of group incentive systems of pay, in workplaces practices, and in worker assessment of workplace culture.

2) The firms that use shared capitalist modes of compensation have policies that allow greater employee participation in decisions and greater information sharing than other firms, and have a more positive workplace culture than other firms.

3) The combination of group incentive pay and policies that empower employees and create a positive workplace culture increases employee intent to stay with a firm, lowers voluntary turnover, and raises return on equity.

The next section places our study in the context of the large extant body of literature on group incentive pay and worker and firm performance. We then describe the GPTW sample and document the substantial differences in the use of shared capitalist modes of pay and work practices even among these self-selected good employers. The following sections present our estimates of the linkages between modes of compensation and work practices and workplace culture and our estimates of the impact of these factors on economic outcomes. We conclude with a summary of results and discussion of outstanding issues. 


\section{The study of "shared capitalist" compensation and practices}

There are over 100 studies of the relation between group incentive pay and related personnel practices and firm and worker performance. Most of the studies compare firm performance of firms with and without these forms of pay in cross-section data. ${ }^{1}$ Some studies examine firms before and after their adoption of a group incentive compensation scheme, or control in other ways for selection bias. ${ }^{2}$ Meta-analyses analyzing the combined results of studies show statistically significant positive associations of employee ownership and profitsharing with firm performance. ${ }^{3}$

There is also a wide dispersion in the magnitude of estimated effects within and across studies. Many analysts and practitioners interpret this dispersion as indicating that the context in which management establishes a group compensation system affects its success. Firms cannot simply institute a program that links worker pay to the firm performance and expect the firm to do better as if the method of pay was a technological fix to some engineering problem. ${ }^{4}$ "To get the productivity-enhancing effects, something more may be needed-something akin to developing a corporate culture that emphasizes company spirit, promotes group cooperation, encourages social enforcement mechanisms, and so forth” (Weitzman and Kruse, 1990: 100). Bundling equity and profit sharing with financial information and participation in decision

1

For reviews of the employee ownership literature see Blasi 1988; Doucouliagos, 1995, Kruse and Blasi, 1997, Kaarsemaker, 2006, Freeman, 2007, and Kruse, Freeman, and Blasi 2010. For a review of the broad-based stock option literature see Blasi et al., 2003. For reviews of the profit sharing and gain-sharing literatures see Weitzman and Kruse, 1990, Bullock and Tubbs, 1990, Kruse, 1993, OECD, 1995, Doucialiagos, 1995, Welbourne and Mejia, 1995.

2

One field study implemented random assignment of profit sharing at 3 of 21 establishments within a firm, finding that the performance of those establishments improved relative to the control group (Peterson and Luthans, 2006); A laboratory experiment among subjects organized into employee-owned "firms" found higher productivity (Frohlich et al., 1998). Our study using an employee survey before and after the introduction of a profit sharing plan found an increase of anti-shirking behaviors. (Freeman, Kruse, and Blasi 2010: 31). Two studies find that average worker quality based on observables did not change as compensation changed from individual to group incentives, while average worker performance improved (Weiss, 1987; Hansen, 1997).

3

Doucialiagos, 1995; Kruse and Blasi, 1997; Weitzman and Kruse, 1990.

4

Our 2010 analysis (Kruse, Freeman, and Blasi) of two nationally representative surveys and over 41,000 employee surveys in companies with shared capitalist modes of compensation found that the effects of these plans on performance-related attitudes and behaviors was greatest in firms that also trusted employees to work well without close supervision, paid base wages at or above market, and offered good job security, training, and employee involvement in decisions. This suggests that the dispersion in results around the positive average in the literature may be due in part to policies that accompany the incentive systems. Pendleton and Robinson (2010) find that employee ownership appears to interact with formal employee involvement programs in affecting performance when a minority of employees participate in employee ownership but that ownership affects performance directly when a majority of employees participate. 
making can enhance worker contributions to the firm by creating employment relationships based on congruent psychological contracts. Such a bundle can form the basis of trust and aligned interests between workers and the employer (Rousseau and Shperling 2003: 564-565).

One likely reason why a group incentive system needs support from other practices to improve outcomes is that it must overcome the free rider or $1 / \mathrm{N}$ problem that plagues all forms of collective action. In an incentive plan with $\mathrm{N}$ workers, the payoff to the individual from his or her effort is diluted because each individual receives only 1/Nth of the reward from their work. It is rational to free ride on the effort of others, but if most workers do that, the group incentive system fails. In theory, workers can solve the free rider problem by establishing and enforcing work norms for high effort (Axelrod, 1984; Fudenberg and Maskin, 1986) but neither theory nor empirical studies specify what it takes to overcome the $1 / \mathrm{N}$ problem in different settings. ${ }^{5}$ On the employers' side, one interpretation of successful programs is that they work like a "gift exchange" (Akerlof, 1983) from the employer to employees in which the plans draw on feelings of reciprocity that help establish norms for greater effort and cooperation. On the workers' side, some workers may step up and monitor fellow employee efforts to enforce the work norm. New empirical work indicates that proportionately more workers in establishments with group incentive systems than workers in establishments without such incentives intervene with fellow employees to improve performance (Freeman, Kruse, Blasi, 2011: 77-104). This demonstrates that worker self-monitoring is a real channel for policing a group incentive system. But it pushes the free rider question back a stage rather than eliminating it, for it raises the free rider question of why some workers undertake the monitoring activity rather than "letting Joe do it".

The GPTW data set provides a new way to illuminate the effects of group incentive compensation systems and accompanying policies and practices on economic outcomes, and to assess the complementarity among shared capitalist forms of compensation and particular ways of operating a firm. To our knowledge it is the largest sample of firms and workers in the United States that contains data on shared compensation practices, workplace practices, worker attitudes and responses to policies, and measures of firm performance. But it is a highly nonrepresentative sample. Only firms that view themselves as having sufficiently good labor practices to make the 100 best list are likely to take the time and resources to apply to the Great Place to Work ${ }^{\circledR}$ Institute for consideration in the competition.

It is usual to regard a non-representative sample as inferior to a representative sample, but in this case the fact that the sample come from the upper tail of those with good labor practices is a strength. One weakness of most studies that link shared capitalist pay and practices to outputs, including our own earlier work, is that there is always the potential that some unobservable characteristic of the employer, workplace, or situation of the firm overcomes the $1 / \mathrm{N}$ problem so that the group incentive pay system succeeds. If firms debating whether or not to introduce these modes of compensation cannot replicate that unique attribute or find their own way to overcome

5

Laboratory experiments show that cooperation occurs more often than predicted by models of self-interest, and is more likely when participants form a group identity by talking with each other before making their choices (Dawes and Thaler, 1988; Kahneman, Knetsch, and Thaler, 1991). Empathy with co-workers through communication can help develop and enforce norms that support higher performance (Kandel and Lazear, 1992; Lazear, 1992). 
the $1 / \mathrm{N}$ problem, they are unlikely to have the same success with group incentive pay as firms that have succeeded by adopting those forms of pay and practices. Having a sample of firms that view their labor practices as exemplary allows us to sign the likely selection bias as a downward bias.

To see this, consider a comparison of two applicants to the 100 best competition under the assumption that firms apply only if their workplaces exceed some level of good practice, $\mathrm{P}^{*}$. Firm A has a group incentive compensation policy (and/or other shared capitalist modes of operating) so that it produces a workplace with good practice $\mathrm{Pa}$, with $\mathrm{Pa}>\mathrm{P} *$. Firm $\mathrm{B}$ does not have such a policy but has other attributes that leads it to view its workplace practices $\mathrm{Pb}$ as making it exemplary, $\mathrm{Pb}>\mathrm{P}^{*}$. Firm B's positive unobservable characteristic/policy makes it comparable to firm A with its shared capitalist mode of pay. If both the good workplace practices of firm A and the unobservable characteristics of firm B produce better economic outcomes, comparisons of A and B would yield smaller differences in outcomes than would comparisons of A with some randomly drawn firm from the population of firms.

The empirical task for the rest of this study is twofold: 1) to see whether there are substantial differences in the use of group incentive modes of pay and related personnel policies and practices within the select group of GPTW firms that will allow us to study the relation between these ways of operating the firm's business and worker and firm outcomes; and 2) to estimate whether within this group those modes of pay work separately or in combination with other practices to affect worker and firm outcomes.

\section{The “100 Best Companies to Work For ” Applicant Data Set}

The data come from two surveys collected by the Great Place to Work® Institute: 1) the "Culture Audit" survey of workplace practices that representatives of companies fill out when they apply for selection to the 100 best list, and 2) the employee survey that the Institute gives to 200-300 representative employees in each company, in order to measure employee attitudes and perceptions of the company. The Institute gave us access to the surveys for the firms that made the 100 best list and those that applied and did not make the list under a confidentiality agreement which allowed us to link the data to other data sources and to analyze it on an Institute server.

The Institute developed the Culture Audit from intensive fieldwork with corporations over the last fifteen years. It contains information on the availability of shared capitalism plans, and other work practices and performance outcomes. About 400 companies supply Culture Audit and employee survey data each year as part of their application to be considered one of the "100 Best Companies to Work For in America." Our sample contains 780 companies over the 3year span 2005-2007. It has 1312 company-year observations (reflecting applications in multiple years by some of the companies). Three hundred seventy five of the companies are public, which allowed us to add measures of their economic performance from Standard \& Poors' Compustat to the data set. The remaining firms are privately-held, for which we do not have information on performance. The publicly owned companies are large companies traded on the NYSE and the NASDAQ. Based on Compustat data, our public company sample captures a substantial proportion of US public company activity: $10 \%$ of total sales, $10 \%$ of total employment, and 20\% of the market value of all publicly traded corporations in 2007.

The employee surveys provide information on 305,339 employees or an average of 232 
surveys per company-year. While firms can be tracked over time, individual employees cannot be tracked over time.

Our data are multilevel. Some are at the firm level. Some are at the individual level within firms, which can be aggregated to firm level. Data on compensation policies and turnover come from management responses on the Culture Audit. Data on firms' financial performance, which is limited to public companies, come from the linked Compustat data file. These two sources of data allow us to examine the effect of firm practices on firm outcomes in a different way than the two studies that have used the publicly available list of " 100 best places to work" firms to assess the effects of good labor practices on firm performance. Edmans (2011) and Faleye and Trahan (2011) compare the stock market returns of firms that make the "100 best list" to the returns of industry and size-matched firms that are not on the list. They both find that companies on the 100 best list have higher shareholder returns, at least over some time periods. ${ }^{6}$ We complement their studies by comparing performance among applicant firms with different human resource management policies that allows us to assess the impacts of particular policies. Information on employee empowerment and workplace culture comes from the employee responses to the randomly distributed surveys administered by the Institute. In some calculations we average individual reports to the company level, which allows us to test the potential mediating effects of employee reported patterns on the relation between modes of compensation and policy on firm outcomes. The individual responses also allow us to examine the relationship of worker reported measures of employee empowerment and workplace culture on individuallevel outcomes, such as the intent to stay with the firm, and to link those outcomes to firm-level compensation policies.

Having data from both employees and managers and objective measures about firm performance avoids the problem of common method bias that often plagues studies with data from a single source or respondent, be it workers or managers With only a single source, there is a danger of spurious covariance in variables due to the respondent's report on different attributes having a common base. For example, workers who report high trust in management may also report that they are more likely to stay with the firm, producing a strong relation among individuals, but if high trust workers are randomly distributed among establishments there may be no relation between trust and likelihood of staying at the establishment level. The manager may report positively on practices that he or she believes are being implemented and view the firm's performance positively, while workers may have a different view on how the firm actually

6

Using only those corporations designated as the Best Companies, the Edmans study constructs both a valueweighted and an equal-weighted portfolio from 1984-2009, both of which have better long-run stock returns above the risk-free rate with the findings robust to controls for industries and outliers. The study hypothesizes that "employee satisfaction" as determined by a firm's appearance on the Best Company list, plays a key role in this linkage, noting that two-thirds of the ranking for the list is based on the random employee surveys of employees. The Faleye and Trahan study also examines only the companies designated Best Companies from 1998-2005 and finds a statistically significant average abnormal stock price reaction to the announcement of the Fortune list. In addition, the Best Companies outperform comparable firms on measures of employee productivity, firm-level total productivity, profitability and firm value with highly robust results. The study hypothesizes that "labor-friendly" policies play a key role in this linkage and tests these ideas using a separate independent measure of "labor-friendly" policies using a different corporate social responsibility data set. 
operates on the ground, and company financial data may give yet a different picture of how the firm is performing. Having information from three sources provides a test of whether patterns found with one type of data hold in others. In the case of turnover, we have manager-reported data on company voluntary turnover as well as employee reports of their intent to stay at the firm that allows us to check whether relations found at the worker level are also found at the firm level.

Table 1 provides detail on the group incentive compensation systems used by firms in the data set over all company-years. The table demonstrates one key fact - that there is substantial variation in the compensation systems among firms in the GPTW data. Approximately one-sixth of firms (17.6\%) report that they have an Employee Stock Ownership Plan (ESOPs), 18.1\% report cash profit/gain-sharing plans, and 22.3\% report deferred profit sharing plans. Given the widespread use of stock options to reward executives, the most common form of group incentive pay is granting stock options, which $44.5 \%$ of firms report. While most publicly-traded firms give stock options to some subset of their top managers or employees, this lower incidence in the sample reflects the large segment of the sample made up of closely-held firms which do not utilize employee stock options to the same extent.

There is also substantial variation in the attributes of the group incentive plans among firms that use these modes of pay. Of the companies with an ESOP, the mean proportion of shares held by the ESOP is $17.4 \%$, The median proportion is a much lower $5.9 \%$ - a divergence due to the fact that $9.1 \%$ of the firms are majority employee owned with over $50 \%$ of the shares held by the ESOP. Of the companies with profit or gain sharing plans, the average cash plan provided to an employee is $7.2 \%$ of annual pay while the average deferred profit sharing plan provided a contribution equaling $6.5 \%$ of employee pay, on top of the base pay. In both cases the distribution is concentrated below the mean so that the median payout or contribution is notably smaller than the mean. Finally, of the companies with stock options, the average percent of employees granted stock options was $20.6 \%$ while the median was $6.5 \%$. Three quarters of the firms gave options to less than $25 \%$ of employees while $16.4 \%$ of the companies were broadbased in that they granted stock options to more than half of their employees.

In sum, the table shows a wide variation among firms in both the presence of different modes of group incentive pay and in the extent of such pay. This variation is necessary for us to make any inferences about the effects of shared capitalist modes of pay and accompanying practices on outcomes from the GPTW sample.

Because the Culture Audit provides information on the details of compensation systems that reflect the extent to which the systems offer incentives to representative groups of workers, which creates a host of variables, for ease of analysis we combine the compensation measures into a single statistic. This is a thermometer-style index focusing on the extent of shared capitalist forms of pay, where we give high scores to firms whose compensation system rewards more workers through group incentive pay and/or where incentive pay is a potentially larger share of worker earnings. The index is a summated rating of eight items that accord one point each for 1) Having an Employee Stock Ownership Plan (ESOP), 2) Having an ESOP owning $50 \%$ or more of the company, 3) Having a stock option plan that covers $25 \%$ or more of employees, 4) Having a stock option plan that covers $50 \%$ or more employees, 5) Having a cash profit/gain-sharing plan, 6) Having a cash profit/gain sharing paying more than the median percent of pay, 7) Having a deferred profit sharing plan, and 8) Having a deferred 
profit sharing with a contribution above the median percent of pay. With eight items the range of the scale is 0 to 8 .

Table 2 gives the distribution of firms by this measure and some summary statistics for this "shared capitalist compensation index". Over half of the firm-year observations meet none of the eight criteria and thus have a score of zero. In these cases, the firms have no shared capitalism in the specified years. They are effectively the firm B "control group" for inferring the effects of shared capitalist modes of incentive pay on outcomes within the GPTW sample. Six percent of the observations have scores of 3 or more, with a maximum score of 5 . They are effectively the firm A "treatment group" for inferring the effects of shared capitalist pay. In the ensuing analysis we relate the index to work practices and measures of workplace culture and economic outcomes and report in the appendices on the link between the components of the index and relevant outcomes.

\section{Other policies and practices}

Table 3 provides descriptive statistics on the measures of workplaces practices and workplace culture on which we focus.

With respect to workplace practices, we examine three variables that theory and prior research suggest are complementary to shared capitalism ${ }^{7}$ : high-trust supervision, high participation in decisions, and high information sharing. These are highly correlated variables that we averaged to form a single index which we label "employee empowerment" (alpha=.890). For workplace culture we use six measures: workers assessments of team or family feeling, employee cooperation, employee willingness to give extra to their work, the feeling that one receives a fair share of company profits, the Great Place to Work Trust Index $\subset$, and the perception that this is a great place to work. The Institute developed the Trust Index@ as a summary measure of employee perceptions of the company. It includes all items from the employee survey, grouped into five dimensions and averaged across the dimensions. ${ }^{8}$ It provides a broad measure of company culture.

Table 3 also presents descriptive statistics for our individual-level measure of intent to stay and company-level performance measures of voluntary turnover and return on equity (ROE).

Turnover is one of the most important measures of worker satisfaction with how a firm operates. The ubiquitous finding from studies of job satisfaction is that low satisfaction is associated with high quits, which makes up most voluntary separation (retirement being the other part of voluntary separation). The question to workers on intent to stay with the firm is forwardlooking and subjective while the company-level measure of voluntary turnover is backwardlooking and objective. Aggregating the worker reports on intent to stay gives us a firm-level

7

See, for example, Dube and Freeman (2010); Conyon and Freeman (2004).

8

The five dimensions are labeled camaraderie (10 items, alpha=.94), credibility (13 items, alpha=.96), fairness (12 items, alpha $=.93$ ), pride (8 items, alpha $=.93$ ), and respect (13 items, alpha $=.94$ ). The Trust Index@ that averages these five dimensions has an alpha of .970. We exclude the "intent to stay" item since we examine the relationship between the Trust Index $\odot$ and intent to stay in Table 7. 
measure that we have correlated with the firm-level measure of turnover. To the extent that the practices or conditions that produce high or low turnover are stable over the period, the two measures should be negatively related. Their correlation is -.245 .

Turning to firm outcomes, the most widely used financial measure of the performance of firms is return on equity (ROE), which reflects the value of the firm to shareholders. But ROE varies across industries depending on riskiness and other factors. We have "adjusted” ROE from a robust regression of ROE on forty industry dummies and firm size, separately by year, for the entire Standard and Poor's Compustat data set. With this method we have effectively controlled for industry-specific risk factors that may vary over time. The resulting value represents the company's performance relative to public companies of the same size in the same industry in the same year. There were some extreme values in ROE among the GPTW companies after this adjustment, so we ran all regressions both with and without trimming the upper and lower 1\% of ROE within the GPTW sample. The basic results were similar; here we present the results using the trimmed measure. The mean value of .039 for adjusted ROE indicates that the applicants had an average ROE that was 3.9 percentage points higher than the industry-year average for firms of the same size, consistent with the idea that these are better-performing firms in general. ${ }^{9}$

\section{Shared Capitalist Compensation and Complementary Workplace Practices}

As noted, a key issue in the analysis of group incentive systems is the extent to which they are accompanied by other work practices and workplace culture, presumably due to the complementarity of the pay and workplace operations. ${ }^{10}$ Table 4 summarizes the results of analyzing the relation between group incentive modes of pay and workplace practices and culture in the GPTW data set. It records the coefficients from regression of workers' reports on each of the measures of workplace empowerment and culture on the shared capitalist index variable.

The regressions show that employees in companies with higher values on the shared capitalist index are more likely to report high-trust supervision, participation in decisions, information sharing, and more favorable outcomes on all of the culture measures. The calculations in appendix table A, which replace the index with its underlying components namely, dummy variables for presence or absence particular forms of pay and continuous variable measures of its extent - show that ESOP variables are most consistently significantly

\section{9}

This is higher than Edmans' (2011) estimate of an excess return of 2.1\% annually over the 1984-2009 period for a portfolio made up of Best Company winners relative to a portfolio of same-industry firms.

10

In our 2010 book we analyzed two nationally representative surveys and over 41,000 employee surveys in shared capitalism companies, finding that these plans have the most positive effects on performance-related attitudes and behaviors when they are combined with high-trust supervision (trusting employees to work well without close supervision), base wages at or above market, and high-performance policies (job security, training, and employee involvement in decisions). Without these policies these plans can have no or negative effects, indicating that the dispersion in results across the 100+ studies we have reviewed may be explained in part by the types of policies that do or do not accompany shared capitalism. Other recent studies finding evidence of complementarities between shared capitalism and workplace policies include Jones et al. (2010) and Pendleton and Robinson (2010). 
positively related to the practices and attitudes, with deferred profit-sharing as the second most significantly related. It appears that managers tend to have supportive cultures where shared capitalism practices are prevalent.

\section{Model Specifications and Results}

Standard regression analysis is an appropriate tool to estimate the links from the compensation and workplace practice variables on outcomes in each of the three years of our data set taken independently. But because many firms apply to the Great Place To Work competition in more than one year, we can do better than simple OLS in an analysis that pools the data over the three years: the existence of the same firm in two or three of the years allows us to take account of firm-specific factors. In the 2005-2007 GPTW data set, 480 companies applied to the competition once in this period, 168 applied twice, and 182 applied three times, which creates a distinct structure to the error terms associated with an individual establishment. To exploit this pattern, we use a random effects specification of the model that uses both within-firm and between-firm variation to estimate the parameters linking variables.

First we examine the overall relationship of shared capitalism to the other outcomes using the following equations:

$$
\begin{aligned}
& \mathrm{Y} 1_{\mathrm{ijt}}=\mathrm{a}+\mathrm{b} 1 * \mathrm{SC} \mathrm{jt}_{\mathrm{jt}}+\mathrm{b} 2 * \mathrm{X} 1_{\mathrm{ijt}}+\mathrm{b} 3 * \mathrm{X} 2_{\mathrm{jt}}+\mathrm{b} 4 * \mathrm{R}_{\mathrm{j}}+\mathrm{e}_{\mathrm{ijt}} \\
& \mathrm{Y} 2_{\mathrm{ijt}}=\mathrm{a}+\mathrm{b} 1 * \mathrm{SC} \mathrm{j}_{\mathrm{jt}}+\mathrm{b} 2 * \mathrm{X} 1_{\mathrm{ijt}}+\mathrm{b} 3 * \mathrm{X} 2_{\mathrm{jt}}+\mathrm{b} 4 * \mathrm{R}_{\mathrm{j}}+\mathrm{e}_{\mathrm{ijt}} \\
& \mathrm{Y} 3_{\mathrm{jt}}=\mathrm{a}+\mathrm{b} 1 * \mathrm{SC} \mathrm{jt}_{\mathrm{jt}}+\mathrm{b} 2 * \mathrm{X} 2_{\mathrm{jt}}+\mathrm{b} 3 * \mathrm{R}_{\mathrm{j}}+\mathrm{e}_{\mathrm{jt}}
\end{aligned}
$$

where

$\mathrm{Y}_{\mathrm{ijt}}=$ perception of empowerment and culture for individual $\mathrm{i}$, firm $\mathrm{j}$, year $\mathrm{t}$

$\mathrm{Y}_{\mathrm{ijt}}=$ intent to stay for individual $\mathrm{i}$, firm $\mathrm{j}$, year $\mathrm{t}$

$\mathrm{Y}_{\mathrm{jt}}=$ firm performance measure for firm $\mathrm{j}$, year $\mathrm{t}$

$\mathrm{SC}_{\mathrm{jt}}=$ shared capitalism measure(s) for firm $\mathrm{j}$, year $\mathrm{t}$

$\mathrm{X}_{\mathrm{ijt}}=$ employee-level controls for individual $\mathrm{i}$, firm $\mathrm{j}$, year $\mathrm{t}$

$\mathrm{X} 2_{\mathrm{jt}}=$ company-level controls for firm $\mathrm{j}$, year $\mathrm{t}$

$R_{j}=$ firm-level random effect for firm $j$

$e_{i j t}^{j}=$ error term for individual $i$, firm $j$, year $t$

$\mathrm{e}_{\mathrm{jt}}=$ error term for firm $\mathrm{j}$, year $\mathrm{t}$

The X1 controls include individual-level employee demographic information (gender dummy, full-time dummy, 6 dummies for race/ethnicity, 5 dummies for age category, 7 dummies for occupation, 6 dummies for tenure category) and the X2 controls include company-level characteristics (defined benefit pension plan dummy, natural logarithm of total employment, unionized percent of workforce, whether publicly-held, age of company, dummies for services and manufacturing, and natural logarithms of average hourly pay for largest hourly-paid group and average salary for largest salaried group).

In the next stage of analysis we examine the potential moderating effects of empowerment and culture by using interactions with shared capitalism. 


$$
\begin{aligned}
& \mathrm{Y} 2_{\mathrm{ijt}}=\mathrm{a}+\mathrm{b} 1 * \mathrm{Y}_{\mathrm{ijt}}+\mathrm{b} 2 * \mathrm{SC} \\
& \mathrm{jt}
\end{aligned}
$$

where

$\overline{Y 1}=$ mean of $\mathrm{Y} 1$ variable across individuals in firm $\mathrm{j}$, year $\mathrm{t}$

The b3 coefficients will indicate whether empowerment and culture moderate the effects of shared capitalism.

Our model for the avenues through which shared capitalism may affect worker and firm outcomes is presented in Figure 1. ${ }^{11}$

\section{Effects on Turnover}

We next examine the links among intent to stay, voluntary turnover, the shared capitalist index of rewards, and the complementary work practices and workplace culture.

Panel A of Table 5 summarizes calculations of the effect of shared capitalist compensation and the empowerment measure of workplace practices and the Trust Index $\subset$, introduced separately and interactively with the shared capitalist index on the worker level turnover measure of intent to stay. The figures in line 1 show that the index of shared capitalist pay by itself is moderately related to turnover behavior: it raises intent to stay. But its impact is dwarfed by the employee empowerment measure of work place practices in line 2 and by the Trust Index@ measure in line 4. At the individual level these factors have an overwhelming impact on turnover, which makes the shared capitalist index insignificant. This is due in part to the "common source" bias that individuals who are personally well-treated or have trust in the firm are more likely to stay with it whereas workers who feel the opposite at the same workplace are less likely to stay. What is critical to the complementarity story is that the interaction terms are also positive and significant.

The more relevant level of analysis for assessing firm personnel practices is the level of the firm. Panel B of Table 5 summarizes calculations of the effect of shared capitalist compensation and the firm-level averages of the empowerment measure of workplace practices and the Trust Index $(\mathcal{C}$ on the firm-level measure of voluntary turnover. At this level, the shared capitalist variable obtains a negative coefficient by itself that remains substantial with the addition of the empowerment measure in line 7 and the Trust Index@ in line 9. Those variables have significant effects on turnover but they do not "dominate" the calculations as they did in panel A. In the firm-level analysis the interaction terms show the powerful moderating impact of the empowerment measure and the Trust Index $($ on behavior. The interactions are sufficiently strong as to flip the sign on the shared capitalism measure so that it is associated with high voluntary turnover at low levels of worker empowerment or trust, and low turnover at high levels of empowerment or trust.

11

The model in Figure 1 allows for the effects of shared capitalism on worker and firm outcomes to be both mediated and moderated by employee empowerment and culture. We have also tested mediation (results available on request), and the results point toward a richer story of moderation in analyzing the effects of shared capitalism 
These results are illustrated in Figure 2, which is based on regression 8 in Table $5 .^{12}$ "Low" empowerment is defined as the empowerment score for the firm at the $10^{\text {th }}$ percentile, while "high" empowerment is the score at the $90^{\text {th }}$ percentile. In a firm without any shared capitalism, voluntary turnover is predicted to drop slightly from $15.3 \%$ to $14.4 \%$ as a firm moves from low to high empowerment. In a firm with high shared capitalism (the maximum observed score of 5 on the index), voluntary turnover is predicted to drop from $17.6 \%$ to $6.3 \%$ as a firm moves from low to high empowerment. Our interpretation is that employees may react badly to shared capitalism when they are closely supervised and not given the tools to improve performance ("we want you to be inspired by the shared rewards, but we're still going to keep a close eye on you and follow a control-oriented management system”); in this case the shared capitalism may be seen primarily as shifting financial risk onto employees. Kruse, Freeman, and Blasi (2011: 87-88, 94, 96, 152-157) found similar results for the interaction of supervision and high-performance practices.

Finally, panel $\mathrm{C}$ presents a comparable analysis that uses the employee-reported intent to stay aggregated to the firm level. The results match the pattern in panels A and B, indicating that shared capitalist pay interacts with the empowerment and trust measures to decrease turnover whether turnover is measured at the employee or firm level, or with a forward-looking or backward-looking measure.

\section{Effects on company financial performance}

Table 6 examines the effect of shared capitalist compensation and the empowerment measure of workplace practices and the Trust Index@, introduced separately and interactively with the shared capitalist index, on the adjusted return on equity measure that reflects the value to shareholders of these modes of operation. Edmans (2011) found that the firms on the 100 best list had returns on the order of 2 percentage points or so higher than comparable firms, while Faleye \& Trajan (2011) found that "companies selected for the list subsequently outperform comparable firms in terms of long-run stock returns."13 The calculation in line 1 shows that in a sample that includes not only the firms that made the list but those that did not make the list, shared capitalist forms of pay produced significantly higher ROE as well. Addition of the employee empowerment index in line 2 and of the Trust Index $\subset$ in line 4 show that those measures of workplace practices and culture are also associated with higher returns while barely impacting the estimated coefficient on shared capitalist compensation index. But again, the key finding is that it is the interactive effects of the variables that matter. At low levels of employee empowerment, shared capitalist modes of pay reduce ROE whereas at high levels of empowerment, shared capitalist modes of pay raise ROE. Similarly, at low levels of trust shared capitalist modes of pay reduce ROE whereas at high levels of trust, they raise it. We find similar results when empowerment and trust are broken into four dummy variables, allowing non-

\section{2}

A very similar figure is created when empowerment is replaced with the Trust Index@ (not shown but available).

13

See Edmans (2011: 628) and Faleye and Trahan (2010: 33). 
linearities (results available on request). Shared capitalism affects ROE most strongly among firms with values in the top quarter of the Trust Index@.

\section{Conclusion}

Our analysis of the GPTW data set finds that shared capitalist forms of pay are associated with high-trust supervision, participation in decisions, and information sharing, and with a variety of positive perceptions of company culture. At the firm level, shared reward forms of pay are associated with lower voluntary turnover and higher ROE. But it is the interaction between the mode of compensation and work practices and workplace culture that dominates the impact of shared capitalist pay on turnover and ROE. These results confirm the overall findings from prior studies and point to the value of further research on how shared capitalist practices interact with other workplace policies, particularly policies that give workers the means to make a difference in the workplace and help engender a climate of cooperation, as offering the best explanation for the dispersion of results around positive average effects in the literature. 


\section{Bibliography}

Akerlof, George. 1982. "Labor Contracts as Partial Gift Exchange," Quarterly Journal of Economics, Vol. 97, pp. 543-569.

Appelbaum, Eileen, Thomas Bailey, Peter Berg, and Arne Kalleberg. 2000. Manufacturing Advantage. Ithaca: Cornell University Press.

Axelrod, Robert M. 1984. The Evolution of Cooperation. New York: Basic Books.

Azfar, Omar, and Stephan Danninger. 2001. "Profit Sharing, Employment Stability, and Wage Growth,” Industrial and Labor Relations Review, 54(3), pp. 619-630.

Baron, Reuben M., and David A. Kenny. 1986. "The Moderator-Mediator Variable Distinction in Social Psychological Research.” Journal of Personality and Social Psychology, Vol. 51, No. 6, pp. 1173-82.

Benartzi, S. and R. Thaler. 2001. Naïve Diversification Strategies in Defined Contribution Plans,” American Economic Review Vol. 91, No. 1, pp. 79-98.

Berger, Johannes, Claus Herbertz, and Dirk Sliwka, 2011. "Incentives and Cooperation in Firms: Field Evidence,” IZA DP No. 5618, Institute for the Study of Labor, April 2011.

Blasi, Joseph R. 1988. Employee Ownership: Revolution or Ripoff? New York: HarperCollins, Ballinger Books.

Blasi, Joseph, and Douglas Kruse. 1991. The New Owners The Mass Emergence of Employee Ownership in Public Companies and What it Means to American Business. New York: HarperCollins.

Blasi Joseph, Michael Conte, and Douglas Kruse. 1996. "Employee Stock Ownership and Performance Among Public Companies,” Industrial and Labor Relations Review, Volume 50, Number 1, 60-79.

Blasi, Joseph, Douglas Kruse, and Aaron Bernstein. 2003. In the Company of Owners: The Truth About Stock Options (And Why Every Employee Should Have Them). New York: Basic Books.

Blasi, Joseph, Douglas Kruse, and Harry Markowitz. 2010. "Risk and Lack of Diversification under Employee Ownership,” in Douglas Kruse, Richard Freeman, and Joseph Blasi, eds. Shared Capitalism at Work: Employee Ownership, Profit Sharing, Gainsharing, and Broadbased Stock Options. Chicago: University of Chicago Press.

Buchele, Robert, Douglas Kruse, Loren Rodgers, and Adria Scharf. 2010. "Show Me the Money: Does Shared Capitalism Share the Wealth?” in Douglas Kruse, Richard Freeman, and Joseph Blasi, eds. Shared Capitalism at Work: Employee Ownership, Profit Sharing, Gainsharing, and Broad-based Stock Options. Chicago: University of Chicago Press.

Bullock, R.J. and Mark E. Tubbs. 1990. "A Case Meta-Analysis of Gainsharing Plans as Organization Development Interventions," Journal of Applied Behavioral Science, 26, 3, pp. 383-404.

Cappelli, Peter, and David Neumark. 2001. "Do 'High-Performance' Work Practices Improve Establishment-Level Outcomes?” Industrial and Labor Relations Review, July 2001, v. 54, iss. 4, pp. 737-75.

Carstensen, Vivian, Knut Gerlach, and Olaf Hübler. 1995. "Profit sharing in German firms,” in Friedrich Buttler, Wolfgang Franz, Ronald Schettkat, and David Soskice (eds.), Institutional frameworks and labor market performance: Comparative views on the U.S. and German economies. London and New York: Routledge, 168-207. 
Conyon, Martin J., and Richard B. Freeman. 2004. "Shared Modes of Compensation and Firm Performance: UK Evidence,” in David Card, Richard Blundell, and Richard B. Freeman, eds. Seeking a Premier Economy: The Economic Effects of British Economic Reforms, 1980-2000. Chicago: University of Chicago Press, pp. 109-146.

Dawes, Robyn M., and Richard H. Thaler. 1988. “Anomalies: Cooperation,” Journal of Economic Perspectives, Summer 1988, v. 2, iss. 3, pp. 187-97

Doucouliagos, C. 1995. "Worker participation and productivity in labor-managed and participatory capitalist firms: a meta-analysis,” Industrial and Labor Relations Review, 49(1), 58-77.

Dube, Arin, and Richard Freeman. 2010. "Complementarity of Shared Compensation and Decision-Making Systems,” in Kruse, Freeman, and Blasi, eds., Shared Capitalism at Work: Employee Stock Ownership, Profit and Gain Sharing, and Broad-based Stock Options. Chicago: University of Chicago Press.

Edmans, Alex 2011 "Does the stock market fully value intangibles? Employee satisfaction and equity prices” Journal of Financial Economics 101,621-640

Estrin, Saul, and Nicholas Wilson. 1989. "Profit Sharing, the Marginal Cost of Labour and Employment Variability," Draft, Dept. of Economics, London School of Economics (May).

Faleye, Olubunmi and Emery A. Trahan, 2011.” Labor-Friendly Corporate Practices: Is What is Good for Employees Good for Shareholders? “ Journal of Business Ethics Vol. 1, No 1, 127,

Freeman, Richard B., Joseph R. Blasi, and Douglas L. Kruse. 2011. "Inclusive Capitalism for the American Workforce: Reaping the Rewards of Economic Growth through Broad-based Employee Ownership and Profit Sharing," Center for American Progress, Washington, D.C., March.

Freeman, Richard B., Douglas L. Kruse, and Joseph Blasi, 2011. "Worker Responses to Shirking under Shared Capitalism,”,” in Douglas Kruse, Richard Freeman, and Joseph Blasi, eds. Shared Capitalism at Work: Employee Ownership, Profit Sharing, Gainsharing, and Broadbased Stock Options. Chicago: University of Chicago Press.

Freeman, Steven F. 2007. "Effects of ESOP Adoption and Employee Ownership: Thirty years of Research and Experience,” Working Paper \#07-01, Organizational Dynamics Programs, University of Pennsylvania.

Frohlich, N., J. Godard, J. A. Oppenheimer, and F. A. Starke. 1998. Employee versus conventionally- owned and controlled firms: An experimental analysis. Managerial and Decision Economics 19 (4/ 5): 311- 26.

Fudenberg, Drew, and Eric Maskin. 1986. "The Folk Theorem in Repeated Games with Discounting or with Incomplete Information." Econometrica, Vol. 54, No. 3 (May), pp. 53354.

Handel, Michael, and Maury Gittleman. 2004. "Is There A Wage Payoff to Innovative Practices?" Industrial Relations, Vol. 43 (1), pp. 67-97.

Hansen, D. G. 1997. "Worker performance and group incentives: A case study,” Industrial and Labor Relations Review 51 (1): 37- 49.

Hart, R.A., and Olaf Hubler. 1991. “Are Profit Shares and Wages Substitute or Complementary Forms of Compensation?” Kyklos 44, pp. 221-231. 
Hubler, Olaf. 1993. "Productivity, Earnings, and Profit Sharing: An Econometric Analysis of Alternative Models,” Empirical Economics, 18, pp. 357-380.

Ichniowski ,Casey, Kathryn Shaw, and Giovanna Prennushi. 1997. "The Effects of Human Resource Management Practices on Productivity: a Study of Steel Finishing Lines,” American Economic Review, Volume 87. Number 23, 291-313.

Jones, Derek C.; Kalmi, Panu; Kauhanen, Antti. 2010. "Teams, Incentive Pay, and Productive Efficiency: Evidence from a Food-Processing Plant,” Industrial and Labor Relations Review, July 2010, v. 63, iss. 4, pp. 606-626.

Jones, D., T. Kato, and J. Pliskin. 1997. Profit sharing and gainsharing: A review of theory, incidence, and effects. In Handbook of human resources, ed. D. Lewin, D. Mitchell, and M. Zaidi. Greenwich, CT: JAI Press.

Kaarsemaker, Eric C.A. 2006. "Employee ownership and its consequences: Synthesis-generated evidence for the effects of employee ownership and gaps in the research literature.” York, UK: University of York.

Kahneman, Daniel, Jack L. Knetsch, and Richard Thaler. 1991. “Anomalies: The Endowment Effect, Loss Aversion, and Status Quo Bias,” Journal of Economic Perspectives, Volume 5, Issue 1, Winter 1991, 193-206

Kandel, Eugene, and Edward P. Lazear. 1992. "Peer Pressure and Partnerships," Journal of Political Economy, Vol. 100, No. 4 (August), pp. 801-17.

Kardas, Peter; Adria L. Scharf; and Jim Keogh. 1998. "Wealth and Income Consequences of ESOPs and Employee Ownership: A Comparative Study from Washington State," Journal of Employee Ownership Law and Finance. Vol. 10, No. 4, Fall.

Kaufman, Roger T. 1998. "The Effects of Gain Sharing on the Basic Wage: The Case of IMPROSHARE ,” Labour, Autumn 1998, v. 12, iss. 3, pp. 595-610.

Kim, E. Han and Paige Ouimet. 2011 "Employee Stock Ownership Plans: Employee Compensation and Firm Value,” Working paper, Ross School of Business, University of Michigan.

Kroumova, M. 2000. "Investment in employer stock through 401(k) plans: Is there reason for concern?” PhD dissertation. New Brunswick, NJ: Rutgers University.

Kruse, Douglas. 1993. Profit Sharing: Does It Make A Difference? Kalamazoo, MI: W.E. Upjohn Institute for Employment Research.

Kruse, Douglas, and Joseph Blasi. 1997. "Employee Ownership, Employee Attitudes, and Firm Performance: A Review of the Evidence." In David Lewin, Daniel J.B. Mitchell, and Mahmood A. Zaidi, eds., Human Resources Management Handbook, Part 1. Greenwich, CT.: JAI Press.

Kruse, Douglas, and Joseph Blasi. 1999. "Public Opinion Polls on Employee Ownership and Profit Sharing," Journal of Employee Ownership Law and Finance, Vol. 11, No. 3, Summer 1999, pp. 3-25.

Kruse, Douglas, Richard Freeman, and Joseph Blasi (Eds). 2010. Shared Capitalism at Work: Employee Stock Ownership, Profit and Gain Sharing, and Broad-based Stock Options. Chicago: University of Chicago Press. 
Lazear, Edward P. 1992. "Compensation, Productivity and the New Economics of Personnel," in Lewin, David, Olivia Mitchell, and Peter Sherer, eds., Research frontiers in industrial relations and human resources. Madison, WI: Industrial Relations Research Association, pp. 341-80

Organization for Economic Cooperation and Development (OECD). 1995. "Profit sharing in OECD countries,” OECD Employment Outlook, pp. 139- 69.

Pendleton, Andrew; Robinson, Andrew. 2010. "Employee Stock Ownership, Involvement, and Productivity: An Interaction-Based Approach,” Industrial and Labor Relations Review, October 2010, v. 64, iss. 1, pp. 3-29.

Peterson, Suzanne J., and Fred Luthans. 2006. “The Impact of Financial and Nonfinancial Incentives on Business-Unit Outcomes Over Time,” Journal of Applied Psychology, Vol. 91, No. 1, 156-165

Poutsma, Erik, Panu Kalmi, and Andrew Pendleton. 2006. “The Relationship between Financial Participation and Other Forms of Employee Participation: New Survey Evidence from Europe,” Economic and Industrial Democracy, November, vol. 27, no. 4, pp. 637-67.

Renaud, S., S. St- Onge, and M. Magnan. 2004. "The impact of stock purchase plan participation on workers’ individual cash compensation,” Industrial Relations 43(1): 120- 47.

Rousseau, Denise M. and Zipi Shperling 2003. "Pieces of the Action: Ownership and the changing Employment Relationship,” Academy of Management Review, Vol. 28, No. 4, 533-570.

Scharf, Adria, and Christopher Mackin. 2000. "Census of Massachusetts Companies with Employee Stock Ownership Plans (ESOPs)." Boston: Commonwealth Corporation.

Sesil, James, Maya Kroumova, Douglas Kruse, and Joseph Blasi. 2007. "Broad-based Employee Stock Options in the United States: Company Performance and Characteristics,” Management Revue, Vol. 18, No. 2, 2007, pp. 5-22.

U.S. Bureau of Labor Statistics. 2007. National Compensation Survey: Employee Benefits in Private Industry in the United States, 2005, Bulletin 2589. Washington, D.C.: U.S. Bureau of Labor Statistics, May.

U.S. Bureau of Labor Statistics. 2010. National Compensation Survey: Employee Benefits in the United States, March 2010, Bulletin 2752. Washington, D.C.: U.S. Bureau of Labor Statistics, September.

United States General Accounting Office. 1987. Employee Stock Ownership Plans. Washington, D.C.: U.S. General Accounting Office, Report GAO/PEMD-88-1. END

Weiss, Andrew. 1987. "Incentives and Worker Behavior," in Haig Nalbantian, ed., Incentives, Cooperation, and Risk Sharing (Totowa, N.J.: Rowman and Littlefield, 1987), pp. 137-150.

Weitzman Martin. 1984. The Share Economy. Cambridge, MA: Harvard University Press.

Weitzman, Martin L, and Douglas Kruse. 1990. "Profit Sharing and Productivity," in Alan Blinder, ed., Paying For Productivity: A Look at the Evidence. Washington, D.C.: Brookings Institution.

Welbourne, T. M., and L. R. G. Mejia. 1995. Gainsharing: A critical review and a future research agenda. Journal of Management 21 (3): 559- 610. 
Figure 1: Overall model

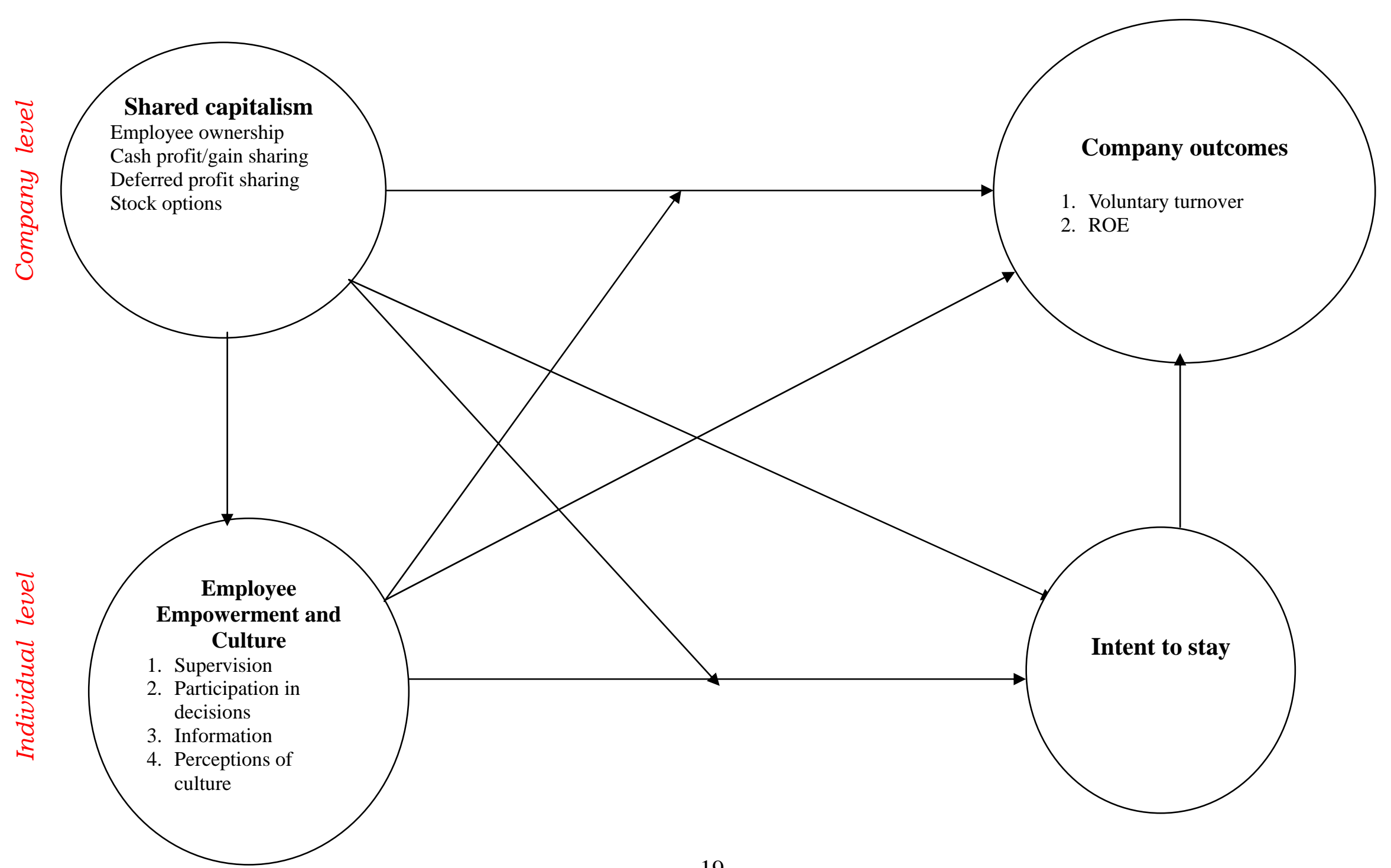




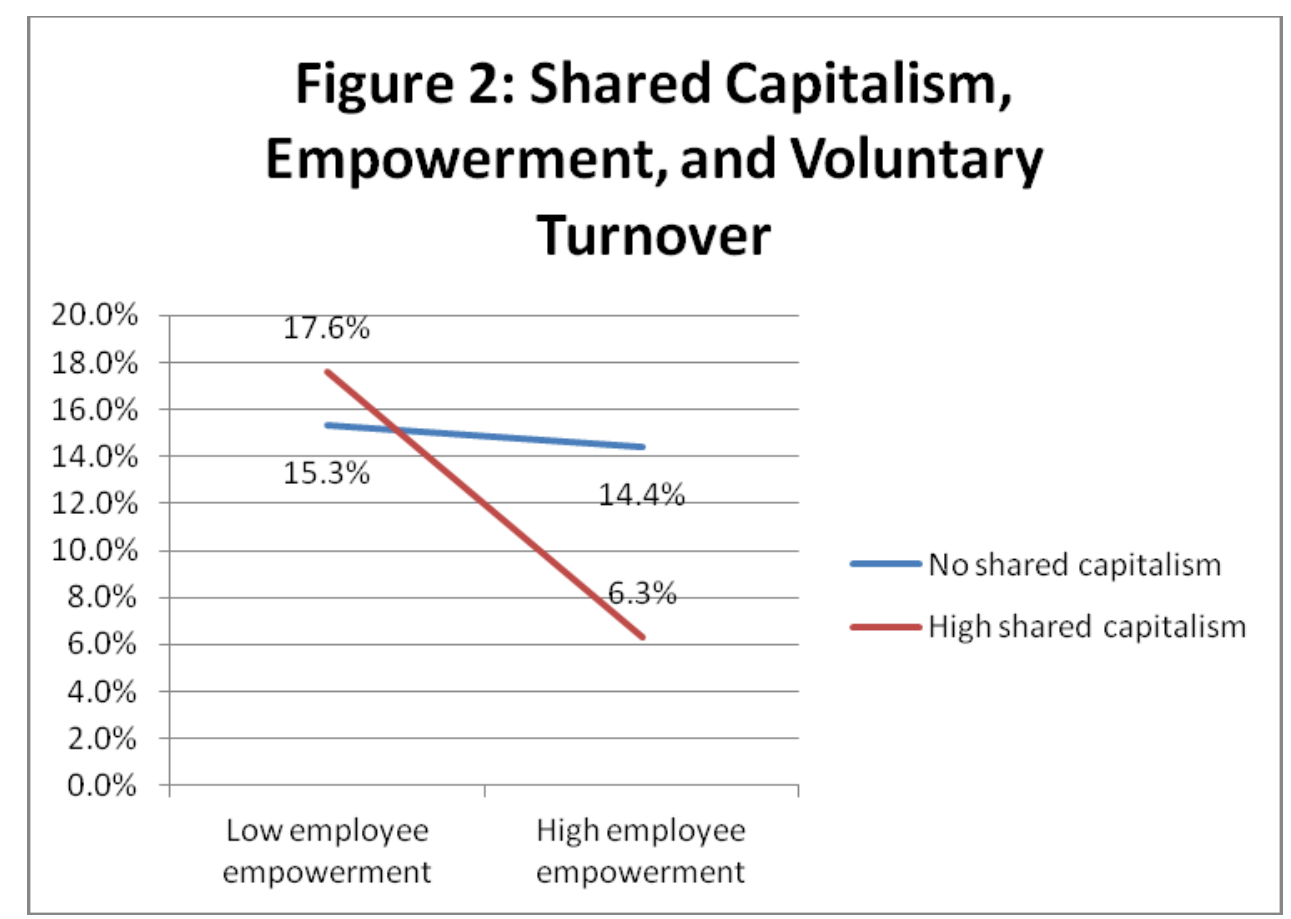


Table 1: Group Incentive Compensation Plans in GPW Database, 2005-2007

Combining all company-years $(\mathrm{n}=1312)$

\begin{tabular}{|c|c|c|}
\hline Plan and characteristics & $\begin{array}{l}\text { Percentage } \\
\text { of firms } \\
\text { with plan }\end{array}$ & $\begin{array}{l}\text { Percentage of firms with attribute if } \\
\text { they have compensation form (s.d. } \\
\text { in parenthesis) }\end{array}$ \\
\hline Employee Stock Ownership Plan & $17.6 \%$ & \\
\hline Of those with, mean \% of company owned by plan & & $17.4 \%(26.9)$ \\
\hline Median \% of company owned by plan & & $5.9 \%$ \\
\hline Percentage with $>50 \%$ of company owned & & $9.1 \%$ \\
\hline Cash profit/gain sharing plan & $18.1 \%$ & \\
\hline Of those with, mean payout as \% of pay & & $7.2 \%(10.5)$ \\
\hline Median payout as \% of pay & & $4.7 \%$ \\
\hline Deferred profit-sharing plan & $22.3 \%$ & \\
\hline Of those with, mean contribution as \% of pay & & $6.5 \%(8.7)$ \\
\hline Median contribution as \% of pay & & $3.9 \%$ \\
\hline Stock options granted in past year & $44.5 \%$ & \\
\hline Of those with, mean \% of employees granted & & $20.6 \%(29.1)$ \\
\hline Median \% of employees granted & & $6.50 \%$ \\
\hline Percentage $<25 \%$ of employees granted & & $74.50 \%$ \\
\hline Percentage $>50 \%$ of employees granted & & $16.40 \%$ \\
\hline
\end{tabular}


Table 2: Summary index of the extent of "shared capitalist" modes of compensation

\begin{tabular}{|l|l|}
\hline $\begin{array}{l}\text { Distribution of Company-Year } \\
\text { observations }(\mathrm{n}=1089)\end{array}$ & Percentage of firms \\
\hline 0 & $52.3 \%$ \\
\hline 1 & $20.9 \%$ \\
\hline 2 & $20.4 \%$ \\
\hline 3 & $4.0 \%$ \\
\hline 4 & $2.0 \%$ \\
\hline 5 & $0.4 \%$ \\
\hline & \\
\hline Mean and Standard deviation & $0.835(1.05)$ \\
\hline
\end{tabular}

Note: Index defined as in text, with one point for 1) an Employee Stock Ownership Plan (ESOP), 2) an ESOP owning 50\% or more of the company, 3) a stock option plan covering $25 \%$ or more of employees, 4) a stock option plan covering $50 \%$ or more employees, 5) a cash profit/gainsharing plan, 6) a cash profit/gainsharing plan paying more than the median percent of pay, 7) a deferred profit sharing plan, and 8) a deferred profit sharing with a contribution above the median percent of pay. 
Table 3: Measures of Employee Empowerment, Workplace Culture, and Firm Performance

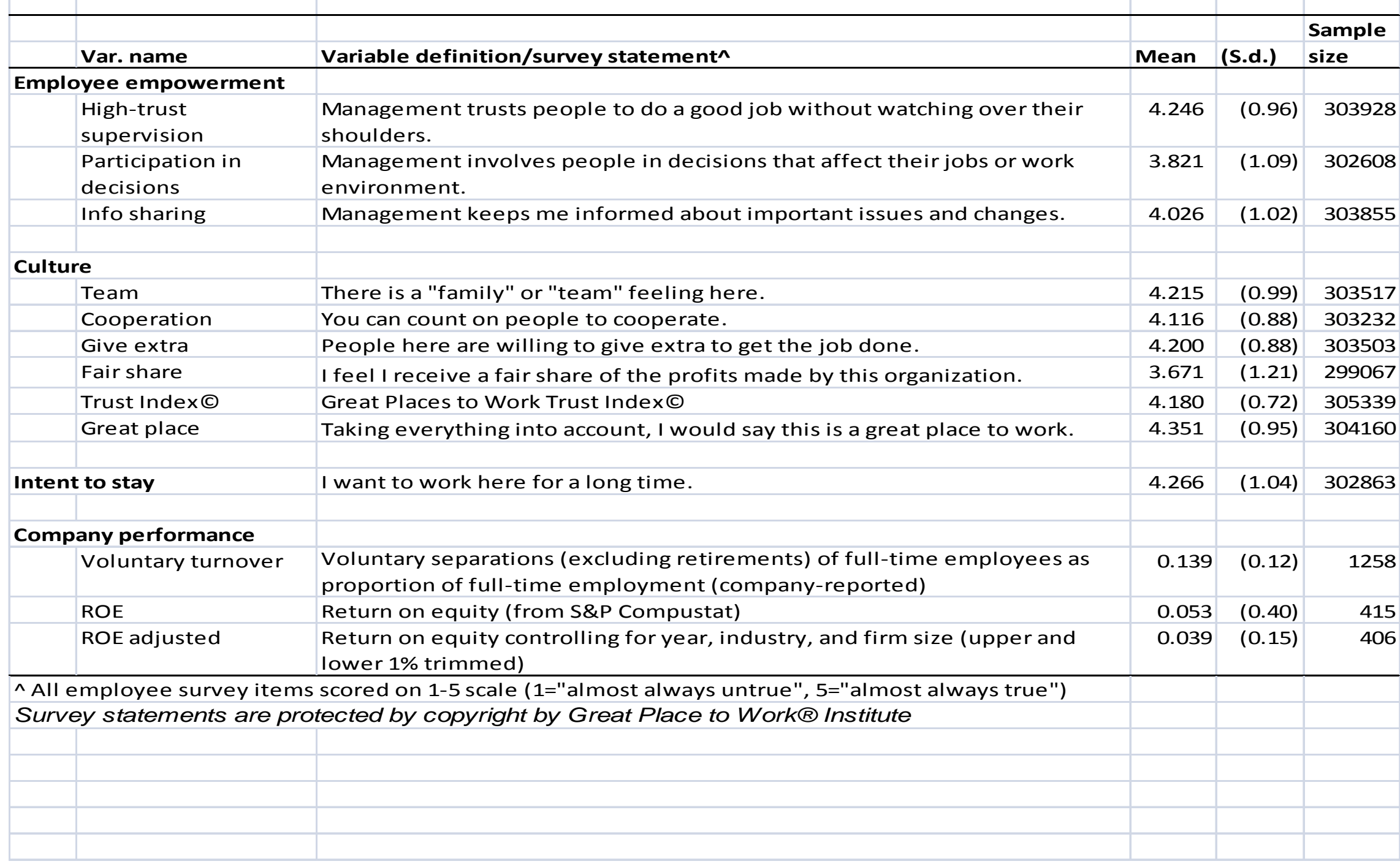




\section{Table 4: Summary of Regressing Workplace Practices and Culture on Shared Capitalist Modes of Pay}

Coefficients and T-Statistics from random-effects maximum likelihood multilevel model estimates. Each row represents results from one regression. See Appendix Table A for fuller results and control variables.

\begin{tabular}{|c|c|c|c|c|}
\hline & $\begin{array}{l}\text { Coefficient, t } \\
\text { statistic in } \\
\text { parenthesis }\end{array}$ & $\begin{array}{l}\text { Wald chi- } \\
\text { square } \\
\text { (38) }\end{array}$ & $\mathrm{n}$ & $\begin{array}{l}\text { Compensation with most } \\
\text { significant impact, followed } \\
\text { by compensation with } 2^{\text {nd }} \\
\text { most significant }\end{array}$ \\
\hline \multicolumn{5}{|l|}{ Workplace Practice } \\
\hline High trust supervision & $.019(3.07) * * *$ & 3663.5 & 241564 & $\begin{array}{l}\text { ESOP, Deferred profit } \\
\text { sharing }\end{array}$ \\
\hline Participation in work decisions & $.012(2.12)^{* *}$ & 7299.8 & 240507 & $\begin{array}{l}\text { ESOP, Deferred profit- } \\
\text { sharing }\end{array}$ \\
\hline Management shares information & $.015(2.09)^{* *}$ & 6390.4 & 241499 & $\begin{array}{l}\text { ESOP, Deferred profit- } \\
\text { sharing }\end{array}$ \\
\hline \multicolumn{5}{|l|}{ Workplace Culture/Attitudes } \\
\hline Team feeling & $.015(2.07)^{* *}$ & 6675.6 & 241227 & $\begin{array}{l}\text { ESOP, Deferred profit- } \\
\text { sharing }\end{array}$ \\
\hline People cooperate & $.012(2.12) * *$ & 5136.1 & 240999 & $\begin{array}{l}\text { ESOP, Deferred profit- } \\
\text { sharing }\end{array}$ \\
\hline Do extra to get job done & $.020(3.33)^{* * *}$ & 7054.4 & 241241 & $\begin{array}{l}\text { ESOP, Deferred profit- } \\
\text { sharing }\end{array}$ \\
\hline Fair share of profits & $.073(6.29)^{* * *}$ & 8825.5 & 237488 & $\begin{array}{l}\text { ESOP, Deferred profit- } \\
\text { sharing }\end{array}$ \\
\hline Great Place to Work Trust Index@ & $.069(2.34)^{* *}$ & 9910.2 & 242587 & $\begin{array}{l}\text { ESOP, Deferred profit- } \\
\text { sharing }\end{array}$ \\
\hline All in all, great place to work & $.022(3.03)^{* * *}$ & 4860 & 241751 & $\begin{array}{l}\text { ESOP, Deferred profit- } \\
\text { sharing }\end{array}$ \\
\hline
\end{tabular}

** $\mathrm{p}<.05 * * * \mathrm{p}<.01$ 
Table 5: Summary of Regressing Turnover Behavior on Workplace Practices, Culture, and Shared Capitalist Modes of Pay

Panel A: Worker level "intent to stay at company"

\begin{tabular}{|l|l|l|l|l}
\hline & $\begin{array}{l}\text { Shared Capitalism } \\
\text { Index }\end{array}$ & $\begin{array}{l}\text { Employee empowerment } \\
\text { index in lines 2 and 3; Trust } \\
\text { Index in lines 4 and 5 }\end{array}$ & Interaction & $\mathrm{N}$ \\
\hline 1 & $.012(.007)^{*}$ & & & 240715 \\
\hline 2 & $.006(.004)$ & $.7365(.002)^{* * *}$ & & 240550 \\
\hline 3 & $-.03(.008)$ & $0.73(.002)^{* * *}$ & $.0076(.002)^{* * *}$ & 240550 \\
\hline 4 & $-0.003(0.003)$ & $1.115(.002)^{* * *}$ & & 240714 \\
\hline 5 & $-0.047(.008) * * *$ & $1.106(.003)^{* * *}$ & $0.011(.002)^{* * *}$ & 240714 \\
\hline
\end{tabular}

Panel B: Employer level, voluntary turnover rate for firm

\begin{tabular}{|l|l|l|l|l}
\hline & $\begin{array}{l}\text { Shared Capitalism } \\
\text { Index }\end{array}$ & $\begin{array}{l}\text { Employee empowerment } \\
\text { index in lines 7 and 8; Trust } \\
\text { Index in lines 9 and 10 }\end{array}$ & Interaction & $\mathrm{N}$ \\
\hline 6 & $-0.008(.004)^{* *}$ & & & 1011 \\
\hline 7 & $-0.007(0.004)^{*}$ & $-0.044(0.016)^{* *}$ & & 1011 \\
\hline 8 & $0.1374(.056)^{* *}$ & $-0.016(.020)$ & $-0.036(0.014)^{* * *}$ & 1011 \\
\hline 9 & $-0.007(.004)^{*}$ & $-0.054(0.019)^{* *}$ & & 1011 \\
\hline 10 & $0.154(.065)^{* *}$ & $-0.023(0.023)$ & $-0.039(0.016)^{* *}$ & 1011 \\
\hline
\end{tabular}

Panel C: Employer level, aggregated worker "intent to stay at firm"

\begin{tabular}{|l|l|l|l|l}
\hline & $\begin{array}{l}\text { Shared Capitalism } \\
\text { Index }\end{array}$ & $\begin{array}{l}\text { Employee empowerment } \\
\text { index in lines 12 and 13; Trust } \\
\text { Index in lines 14 and 15 }\end{array}$ & Interaction & $\mathrm{N}$ \\
\hline 11 & $0.014(.007)^{* *}$ & & & 1024 \\
\hline 12 & $-0.003(0.004)$ & $1.012(0.019)^{* * *}$ & & 1024 \\
\hline 13 & $-0.142(.066)^{* *}$ & $0.985(.023)^{* * *}$ & $0.033(0.016)^{* *}$ & 1024 \\
\hline 14 & $-0.001(.004)$ & $0.810(0.020)^{* * *}$ & & 1024 \\
\hline 15 & $-.125(.067)^{*}$ & $0.786(0.024)^{* * *}$ & $0.031(0.014)^{*}$ & 1024 \\
\hline
\end{tabular}

In Panel A, all regressions are run using a random-effects maximum likelihood multilevel model, with random effects both at the company-year level and the company level. Company-level control variables include defined benefit pension, $\ln ($ total employment), $\ln ($ avg. hourly pay), ln(avg. salaried pay), company age, whether publicly-held, manufacturing, services, and percent 
of employees who are unionized. Individual-level control variables include gender, race/ethnicity (7 dummies), age (5 dummies), tenure (7 dummies), and occupation (7 dummies). In Panels B and C, all regressions use random effects with correction for autogression. Control variables include defined benefit pension, $\ln ($ total employment), $\ln$ (avg. hourly pay), $\ln ($ avg. salaried pay), company age, whether publicly-held, manufacturing, services, and percent of employees who are female, black, Hispanic, Asian, other race, age 26-34, age 35-44, age 45-54, age $55^{+}$, and unionized. 
Table 6: Summary of Regressing Adjusted Return on Equity on Workplace Practices and Culture, and Shared Capitalist Modes of Pay

Coefficients and T-Statistics from random-effects maximum likelihood multilevel model estimates. Each row represents results from one regression.

\begin{tabular}{|l|l|l|l|l}
\hline & $\begin{array}{l}\text { Shared Capitalism } \\
\text { Index }\end{array}$ & $\begin{array}{l}\text { Employee empowerment } \\
\text { index in lines 4 and 5; Trust } \\
\text { Index in lines 8 and 9 }\end{array}$ & Interaction & Wald chi-sq \\
\hline 1 & $0.019(.008)^{* *}$ & & & 26.1 \\
\hline 2 & $0.018(.008)^{* *}$ & $0.112(0.041)^{* * *}$ & & 34.5 \\
\hline 3 & $-0.146(0.126)$ & $0.067(0.053)$ & $0.041(0.032)$ & 36.2 \\
\hline 4 & $0.017(.008)^{* *}$ & $0.161(0.047)^{* * *}$ & & 39.1 \\
\hline 5 & $-0.214(.144)$ & $0.101(.060)^{*}$ & $0.056(0.035)$ & 41.7 \\
\hline
\end{tabular}

All regressions use random effects with correction for autoregression. Control variables include defined benefit pension, $\ln ($ total employment), $\ln ($ avg. hourly pay), $\ln ($ avg. salaried pay), company age, whether publicly-held, manufacturing, services, and percent of employees who are female, black, Hispanic, Asian, other race, age 26-34, age 35-44, age 45-54, age 55+, and unionized. 
Appendix Table A: Predicting Workplace Practices, Culture, and Intent to Stay under Shared Capitalism

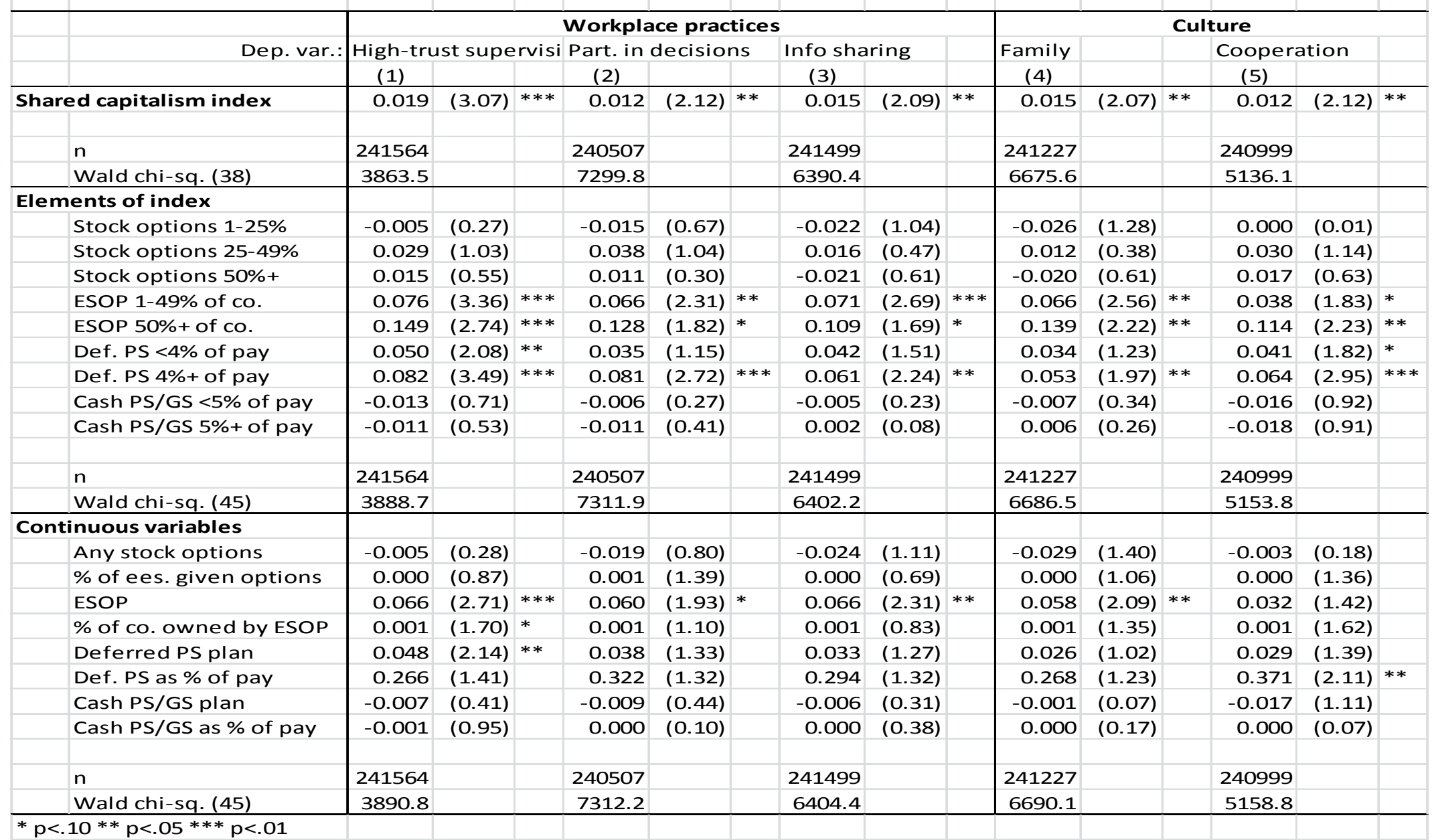

Each column has three regressions: 1) with the shared capitalism index, 2) breaking out the elements of the shared capitalism

index, and 3) using the continuous variables underlying the shared capitalism index. All regressions are run using a random-effects maximum likelihood multilevel model, with random effects both at the company-year level and the company level. Companylevel control variables include defined benefit pension, In(total employment), In(avg. hourly pay), In(avg. salaried pay), company age, whether publicly-held, manufacturing, services, and percent of employees who are unionized. Individual-level control variables include gender, race/ethnicity ( 7 dummies), age ( 5 dummies), tenure ( 7 dummies), and occupation ( 7 dummies). 


\section{Appendix Table A (cont.)}

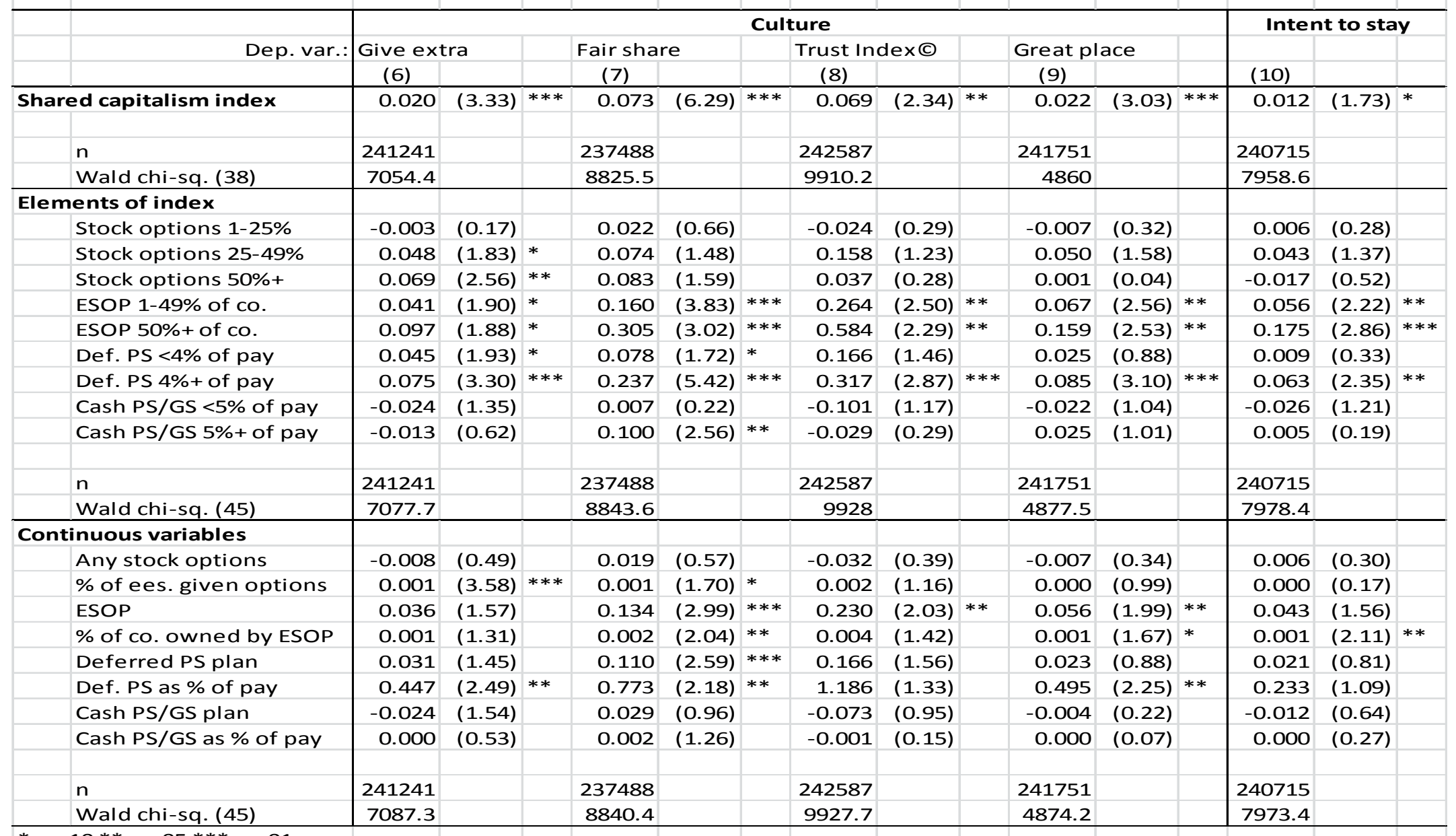

$* \mathrm{p}<.10 * * \mathrm{p}<.05 * * * \mathrm{p}<.01$ 
Appendix Table B: Predicting Firm-level Outcomes with Shared Capitalism

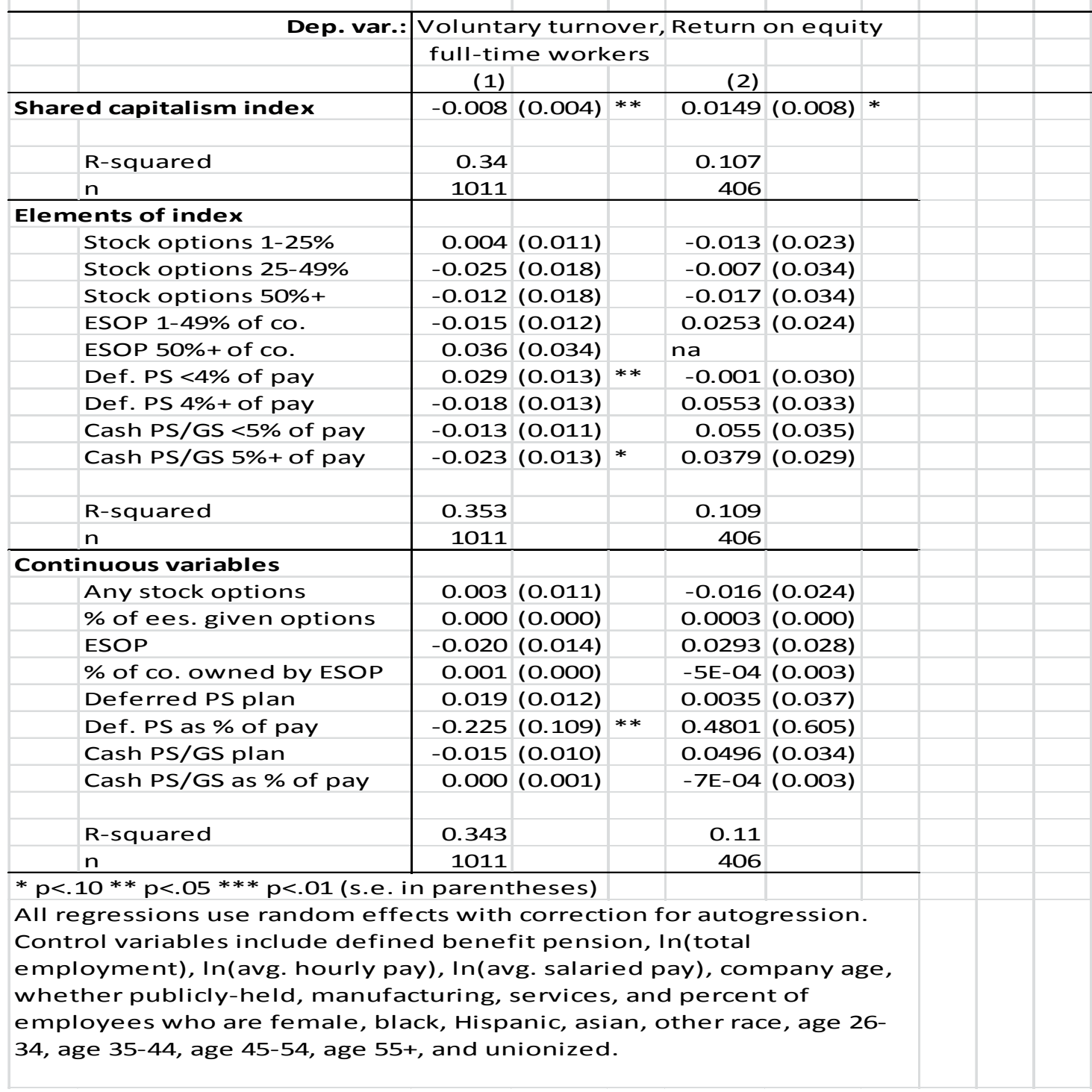

